\title{
Application of the Equal Credit Opportunity Act to Housing Leases
}

\author{
Brian S. Prestes†
}

Landlords often deny a prospective tenant's lease application based on deficiencies in the tenant's credit report. It is unclear whether a landlord is required by federal statute to inform a rejected applicant of the specific reason his credit was deemed deficient. This Comment attempts to resolve this ambiguity in federal law by determining whether the Equal Credit Opportunity Act ("ECOA") applies to leases. If the ECOA applies to leases, then landlords taking adverse action ${ }^{2}$ on lease applications must inform applicants of the specific reasons their applications were denied. The answer to this question is important to the delicate balance between landlord and tenant protections because such information can be extremely valuable to tenants seeking to bring housing discrimination claims under the Fair Housing Act of $1968^{3}$ and the Civil Rights Act of $1866{ }^{4}$ The Comment concludes that courts should resolve this issue by taking into account state law governing permissible terms of housing lease contracts in order to determine whether a given lease involves "defer[red] payment of debt," the necessary element of a "credit" transaction under the ECOA.

This Comment focuses narrowly on whether the ECOA applies to residential housing leases, rather than leases of other sorts, ${ }^{6}$ for several reasons. First, because of the persistence and prevalence of housing discrimination, 'the issue of whether the ECOA applies in this particular

$\dagger$ B.A. 1997, Wake Forest University; J.D. Candidate 2001, The University of Chicago.

15 USC $\$ \S 1691-1691 f$ (1994 \& Supp IV 1998).

2 The ECOA, 15 USC $\$ 1691$ (d)(6) defines "adverse action" as "a denial or revocation of credit, a change in the terms of an existing credit arrangement, or a refusal to grant credit in substantially the amount or on substantially the terms requested." See also 12 CFR $\$ 202.2(c)(1)$ (1999) (defining adverse action).

3 Title VIII of the Civil Rights Act of 1968, codified as amended at 42 USC $\S \S 3601-3619,3631$ (1994 \& Supp II 1996).

4 Act of April 9,1866,14 Stat 27, codified in part at 42 USC $\$ 1982$ (1994).

5 See 15 USC $\$ 1691$ a(d).

6 This Comment does not consider whether the ECOA applies to leases for goods or commercial property.

7 "[R]acial discrimination in housing remains the most visible vestige of formal segregation ... [and] laws prohibiting discrimination in housing have not resulted in the elimination of segregated housing patterns." Leland B. Ware, New Weapons for an Old Battle: The Enforcement Provisions of the 1988 Amendments to the Fair Housing Act, 7 Admin L J Am U 59, 62 (1993). See also James A. Kushner, The Fair Housing Amendments Act of 1988: The Second Generation of Fair Housing, 42 Vand L Rev 1049, 1050-51 (1989) (" $[\mathrm{H}]$ ousing remains the most segregated aspect of American life 
context is uniquely important. Individuals seeking to rent housing are protected from discrimination primarily by the Fair Housing Act ("FHA") and the Civil Rights Act of 1866 ("CRA" or "Section 1982"). Many would-be tenants, however, find they are unable to successfully invoke the protections of such statutes' when landlords deny their applications based on deficiencies in their credit reports. ${ }^{10}$

Second, ECOA-mandated reporting stands to benefit prospective tenants uniquely. Landlords, more than other lessors, use credit reports to determine the likelihood of a prospective tenant's willingness and ability to make timely rent payments. ${ }^{11}$ Under the Fair Credit Reporting Act, ${ }^{12}$ a landlord taking adverse action on a prospective tenant's application based on that tenant's credit report need only inform the applicant that his application was denied based on his credit report and then tell him where he may obtain a copy of his credit report. ${ }^{13}$ Given this limited reporting requirement, landlords may be able to use applicants' credit reports as a pretext for prohibited discrimination based on race, marital status, or other suspect classifications. The tenant may be left to wonder why his credit was insufficient or what he could have done to meet the landlord's credit standards. ${ }^{14}$ Without such information, many tenants are denied leases and similarly denied the only information available for them to know whether their landlords' objections were legitimate and honest as opposed to mere pretext for illegal discrimination. Application

and the greatest failure of the civil rights revolution.").

8 See, for example, Julian Bond, Historical Perspectives on Fair Housing, 29 John Marshall L Rev 315, 323 (1996) (noting that the Fair Housing Act became an important part of the 1968 Civil Rights Act). See also Kushner, 42 Vand L Rev at 1096 (cited in note 7) ("The Fair Housing Amendments Act of 1988 is the most significant civil rights enactment in a generation, providing the mechanisms to enforce the fair housing laws effectively.").

Many state laws also protect tenants from housing discrimination. States may provide protections in addition to, but not falling below, the federal floors established in the FHA and CRA.

9 "Racially segregated housing and the myriad of secondary effects caused thereby, however, are as big a problem today, as they were in 1968." Ware, 7 Admin L J Am U at 116 (cited in note 7).

10 Consumer credit reports, "credit reports" for short, are summaries of individuals' outstanding debt and lines of credit (for example, in the form of mortgages, loans, credit card debts, judgment liens). Credit reports typically disclose an individual's balance, any amount past due, and payment history for all accounts. Credit reports are available for a fee, and are usually obtained from one of the three major credit reporting agencies (Experian, Equifax, and Trans Union).

11 Landlords' use of credit reports to screen tenants is increasing. See Elizabeth Rhodes, Credit Report More Important Than Ever: Landlords, Lenders Rely More Than Ever on Credit Reports that Can Shut You Out of Housing Choices, Greensboro News \& Record E2 (Sept 5, 1999) (stating that as computers have made credit reports both cheaper and more accessible, both large and small landlords have increased their use of credit reports). In fact, credit may be the largest obstacle to home ownership with 38 percent of surveyed applicants citing it as a problem in obtaining a mortgage. See id, citing Fannie Mae 1998 Survey (noting that credit is a larger obstacle to home ownership than discrimination or unemployment).

1215 USC $\$$ 1681-1681u (1994 \& Supp IV 1998).

1315 USC $\$ 1681 \mathrm{~m}(\mathrm{a})$.

14 Creditors may legally use an "empirically derived, demonstrably and statistically sound, credit scoring system" provided such system meets certain criteria. 12 CFR \& 202.2(p) (1999). 
of the ECOA to residential lease transactions would force landlords to provide tenants with the specific reasons their credit reports were inadequate. This information might then be utilized by tenants (and their lawyers) to defeat pretextual defenses by landlords and to better determine the likelihood of a successful lawsuit under the various statutes prohibiting housing discrimination.

Third, the stakes are higher in the residential lease context than they are for commercial leases or leases for the sale of goods. Whether prospective tenants stand to benefit from ECOA reporting requirements is particularly important because housing is a fundamental human need and because discrimination resulting in failure to obtain a given lease must be solved quickly if it is to aid a given prospective tenant unable to rent a particular unit.

This Comment evaluates whether the ECOA applies to residential leases by addressing whether leases involve "defer[red] payment of debt" - the necessary element of "credit" needed to invoke the ECOA. Part I describes the history and mandates of the ECOA, distinguishes the ECOA from other statutes that protect applicants for rental housing, and concludes that applying the ECOA to housing leases would prevent landlords from circumventing the protections of the FHA and CRA and provide valuable information for plaintiffs in housing discrimination cases.

Part II argues that existing authority - the text of the ECOA, agency interpretation, and judicial precedent ${ }^{16}-$ fails to provide a dispositive answer to the question of whether the ECOA includes leases in its definition of "credit" while overlooking mandatory state law controlling the terms of residential leases. Part III suggests that categorization of lease transactions is best accomplished by focusing on the specific terms of the lease under consideration, taking into account applicable state background rules, to determine whether a given lease constitutes "credit."

15 "Shelter is such a basic human need that it should be recognized that alternative housing must and will be obtained during the pendency of complaint enforcement. This reality requires that the enforcement mechanism not only be fair, but fast if the complaint is to be resolved in a way that results in the aggrieved individual's actually acquiring the premises that were denied before settling into another abode." Ware, 7 Admin L J Am U at 116-17 (cited in note 7).

16 The legislative history of the ECOA is unhelpful because it does not discuss whether "credit" includes leases. See, for example, Equal Credit Opportunity Act, S Rep No 589,94th Cong, 2d Sess (1976), reprinted in 1976 USCCAN 403; Depository Institutions Amendments of 1974,S Rep No 902,93d Cong, 2d Sess (1974), reprinted in 1974 USCCAN 6119; Consumer Leasing Act of 1976, S Rep No 590, 94th Cong, 2d Sess (1976), reprinted in 1976 USCCAN 431. See also Brothers $v$ First Leasing, 724 F2d 789, 793 n 10 (9th Cir 1984) (noting that the legislative history of the ECOA does not discuss the "applicability or non-applicability of the ECOA to consumer leases"). Accord, Ferguson v Park City Mobile Homes, 1989 US Dist LEXIS 11010,*7 (N D III) ("there is no legislative history indicating whether [the inclusion of leases] was the intent of the legislature"). The legislative history does, however, speak to the purpose of the statute, which is discussed in Part II.C. 


\section{THE EQUAL CREDIT OPPORTUNITY ACT}

\section{A. History of the Equal Credit Opportunity Act}

On October 28, 1974, ${ }^{17}$ Congress passed the Equal Credit Opportunity $\mathrm{Act}^{18}$ as an amendment to the larger Consumer Credit Protection Act ("CCPA")." Originally, the ECOA's Title VII prohibited discrimination by creditors based on sex and marital status only. ${ }^{20}$ It was intended to address the difficulties faced by women applying for consumer credit. ${ }^{21}$ The ECOA was revised in 1976 to prohibit discrimination based on a host of other categorizations including race, color, religion, national origin, age, receipt of public assistance benefits, and exercise of rights under the CCPA. The purpose of the amendments was to address the difficulties faced by the newly covered groups when applying for consumer credit. $^{23}$

17 The earliest version of the ECOA was passed by the Senate in a 90 to 0 vote in $1973, \mathrm{~S} 2101$, 93d Cong, 1st Sess (June 28,1973), in 119 Cong Rec 25423 (July 23, 1973), but later died in the House. The ECOA was again offered in the Senate às an amendment to HR 11221 and was finally adopted in 1974, when a Conference Committee reconciled S 3492 with HR 14856.

18 Pub L No 90-321, as amended by Pub L No 93-495, 88 Stat 1521 (1974), codified at 15 USC $\S \S 1691-1691 f$ (1994 \& Supp IV 1998). See Kathleen E. Keest, Residential Mortgage Litigation: Credit Discrimination, 989 PLI/Corp 569,576 (1997) (describing the evolution of the ECOA from its earliest incarnations to its current form). For a summary of the ECOA, see Jeffrey I. Langer and Andrew T. Semmelman, Creditor List Screening Practices: Certain Implications Under the Fair Credit Reporting Act and the Equal Credit Reporting Act, 43 Bus Law 1123, 1131 (1988) (summarizing the ECOA's prohibitions and applying the ECOA to credit list screening practices).

1915 USC $\$ \$ 1601-1693 r$ (1994 \& Supp IV 1998).

2015 USC \$ 1691(a) (1974).

21 See Truth in Lending Act Amendments, S Rep No 278, 93d Cong, 1st Sess 3 (1973) (stating that the purpose of the ECOA is to combat discrimination based on sex or marital status and providing specific examples of such discrimination). See also National Commission on Consumer Finance, Consumer Credit in the United States 152-53 (1972) (outlining the problems faced by women applying for consumer credit, including women's greater difficulties applying for mortgages compared to men in the same economic bracket, inability of married women to obtain credit independent of their husbands' credit, and divorced women's difficulties attempting to rely on a credit history obtained during marriage).

22 Equal Credit Opportunity Act Amendments of 1976, Pub L No 94-239, 90 Stat 251 (1976), codified at 15 USC §\$ 1691-1691f (1994 \& Supp IV 1998).

23 The House Committee on Banking, Currency, and Housing proposed a bill prohibiting creditors from discriminating based on race, color, religion, national origin, and age. Equal Credit Opportunity Act Amendments of 1975, HR Rep No 94-210, 94th Cong, 1st Sess 3-4 (1975) (focusing on age discrimination in credit transactions as the motivating factor for HR 5616). The Senate concurred with the House, focusing on both age and race-based discrimination. Equal Credit Opportunity Act Amendments and Consumer Leasing Act-1975: Hearings on S 483, S 1900, S 1927, S 1961 and HR 5616 Before the Subcommittee on Consumer Affairs of the Senate Committee on Banking, Housing, and Urban Affairs, 94th Cong, 1st Sess (1975). Likewise, the Department of Justice supported broadening the terms of the ECOA. Id at 318. On February 2,1976, the Senate passed a bill to amend the ECOA by broadening prohibited discrimination to include discrimination based on age, race, color, religion, national origin, receipt of public assistance benefits, and exercise of rights under the CCPA. Equal Credit Opportunity Act, S Rep No 589, 94th Cong, 2d Sess 1-2 (1976), reprinted in 1976 USCCAN 403, 403-04. On March 9, 1976 the Conference Report was approved, see id, and on March 23, 1976, the Equal Credit Opportunity Act Amendments were signed into law by President Ford. Pub L No 94-239, 90 Stat 251 (1976), codified at 15 USC \$\$ 1691-1691f (1994 \& Supp IV 1998). 
Both the original ECOA and the 1976 Amendments $^{24}$ are implemented by Regulation $\mathrm{B}^{25}$ originally adopted by the Federal Reserve Board ("FRB") in 1977 pursuant to statutory authority granted by the ECOA. ${ }^{26}$ Regulation B defines the relevant terms of the ECOA and provides commentary explaining how the FRB will resolve certain ambiguities when interpreting and applying the ECOA. ${ }^{27}$

\section{B. Mandates of the Equal Credit Opportunity Act}

Today, the ECOA's mandates fall into two categories. First, the ECOA prohibits a "creditor" from certain types of discrimination against an "applicant" in a "credit transaction. " 28 Prohibited discrimination under the ECOA is limited to discrimination based on sex, marital status, race, color, religion, national origin, age, receipt of public assistance, or the good-faith exercise of rights under the CCPA.

Second (and more relevant to this Comment), in furtherance of its anti-discriminatory aim, the ECOA prescribes certain actions creditors must take or refrain from taking. More specifically, the ECOA establishes rules governing the type of information creditors may request during the application ${ }^{30}$ and evaluation process, ${ }^{31}$ and it requires creditors to notify applicants of reasons for adverse action taken on their applications. ${ }^{32}$ Creditors who fail to comply with the notification requirements of the ECOA (or the nondiscrimination provisions of the Act, for that matter), by providing reasons for adverse action that are either insufficiently specific or proxies for illegal discrimination, face potential administrative sanctions, ${ }^{33}$ civil liability, and declaratory action.

24 For clarification, this Comment will use "ECOA" to refer to the 1974 act and 1976 amendments, collectively.

2542 Fed Reg 1242 (1977), codified at 12 CFR $\$ 202$ (1999). In 1985, the FRB revised Regulation B, 50 Fed Reg 48018 (1985), and issued the Official Staff Commentary to Regulation B, which replaces all previous FRB interpretation of the ECOA. 12 CFR $\$ 202$ Supp I.

2615 USC $\$ 1691 \mathrm{~b}(\mathrm{a})(1)$ (1994) requires the Federal Reserve Board to implement regulations that give effect to the ECOA.

2712 CFR $\$ 202$ Supp I. See discussion in Part II.B.

2815 USC $\$ 1691$ (a). These provisions embody the substantive anti-discrimination provisions of the ECOA and may be contrasted with the procedural reporting requirements discussed below.

2915 USC \$ 1691(a). See also Regulation B, 12 CFR \$\$ 202.2(z), 202.4.

$30 \quad 12$ CFR $\$ 202.5$.

$31 \quad 12$ CFR $\$ 202.6$.

3212 CFR $\S 202.9$; 15 USC $\$ 1691$ (d) ("Each applicant against whom adverse action is taken shall be entitled to a statement of reasons for such action from the creditor.... A statement of reasons meets the requirements of this section only if it contains the specific reasons for the adverse action taken.") (emphasis added).

Other ECOA requirements, beyond the scope of this discussion, include mandatory notice of an applicant's right to request a copy of any appraisal on the applicant's home, 12 CFR $\$ 202.5 \mathrm{a}$, limits on when a creditor may require a spouse as a cosigner on a loan, 12 CFR $\$ 202.7$ (d), restrictions on when an existing credit account may be closed, 12 CFR $\$ 202.7$ (c), and restrictions on the way creditors report information to credit reporting agencies, 12 CFR $\$ 202.10$ (b).

3315 USC \& 1691c; 12 CFR \& 202.14(a). 


\section{The ECOA's Reporting Requirement Could Facilitate Enforcement of the Fair Housing Act and Civil Rights Act}
1. The Fair Housing Act and the Civil Rights Act of 1866 already prohibit housing discrimination.

Many consider the Fair Housing Act of 1968 ("FHA") the tenant's primary weapon for fending off discrimination by prospective landlords. The FHA prohibits discrimination in the sale or rental of housing. ${ }^{38}$ An FHA claim involves a three-step inquiry. ${ }^{39}$ First, to make out a prima facie case, a plaintiff need only show that she is a member of a statutorily protected class who applied for and was qualified to rent housing and that her application was denied while the dwelling remained available. ${ }^{40}$ Second, if a plaintiff establishes a prima facie case, the defendant may defeat the claim by showing that his decision to deny the plaintiff's application was based on permissible considerations. ${ }^{41}$ Third and finally, if the defen-

3415 USC $\$ 1691$ e(a)-(d) (stating that defendants violating the ECOA are liable for attorney's fees as well as compensatory and punitive damages up to $\$ 10,000$ or $\$ 500,000$ in a class action); 12 CFR $\S 202.14(b)(1)$.

3515 USC $\S 1691$ (c); 12 CFR $\$ 202.14(b)(1)$.

36 Title VIII of the Civil Rights Act of 1968, 42 USC $\$ \$ 3601-3619,3631$ (1994 \& Supp II 1996).

37 Kushner, 42 Vand L Rev at 1096 (cited in note 7) ("Title VIUI [is] the most attractive litigation strategy. All fair housing cases should now be brought under Title VIII."). But see Ware, 7 Admin L J Am U at 62 (cited in note 7) (stating "the records of the federal agencies responsible for fair housing enforcement have been dismal").

38 The FHA states, in relevant part,

it shall be unlawful-(a) To refuse to sell or rent after the making of a bona fide offer, or to refuse to negotiate for the sale or rental of, or otherwise make unavailable or deny, a dwelling to any person because of race, color, religion, sex, familial status, or national origin. (b) To discriminate against any person [who is a member of one of the above listed groups] in the terms, conditions, or privileges of sale or rental of a dwelling.

42 USC $\$ 3604$. For a comparison of administrative enforcement mechanisms of the FHA and ECOA, see Peter E. Mahoney, The End(s) of Disparate Impact: Doctrinal Reconstruction, Fair Housing and Lending Law, and the Antidiscrimination Principle, 47 Emory L J 409, 411-12 (1998) (noting that the Department of Justice and the Department of Housing and Urban Development apply a more rigorous standard than other agencies).

39 But see Mahoney, 47 Emory L J at 411 (cited in note 38) (arguing that, especially in the case of "disparate impact" claims under the FHA, the standard for liability is "sketchy and haphazard").

40 A plaintiff need only show discriminatory effect, not discriminatory motive, to make out a prima facie FHA case. Soules $v$ United States Department of Housing \& Urban Development, 967 F2d 817,822 (2d Cir 1992) ("To make out a prima facie ... case, a plaintiff must show that he is a member of a statutorily protected class who applied for and was qualified to rent or purchase housing and was rejected although the housing remained available."). See also United States $v$ Yonkers Board of Education, $837 \mathrm{~F} 2 \mathrm{~d} 1181,1217$ (2d Cir 1987) (To state a claim under the FHA, a plaintiff need allege "only discriminatory effect, and need not show that the decision complained of was made with discriminatory intent."); Kushner, 42 Vand L Rev at 1074 (cited in note 7) ("[W]hen a single plaintiff claims a housing denial without regard to a policy or pattern, the plaintiff establishes a prima facie case by proof of disparate treatment, typically a denial to an eligible minority applicant followed by a subsequent transfer to another party or the continued availability of the dwelling in the market.") (footnote omitted).

41 Soules, $967 \mathrm{~F} 2 \mathrm{~d}$ at 822. 
dant provides evidence showing that his decision was motivated by permissible considerations, the plaintiff has an opportunity to show that the stated reasons are merely a pretext for prohibited discrimination. ${ }^{42}$

Much like the FHA, its predecessor, the CRA, ${ }^{43}$ prohibits certain forms of housing discrimination." The CRA states, in relevant part, "[a]11 citizens of the United States shall have the same right, in every State and Territory, as is enjoyed by white citizens thereof to inherit, purchase, lease, sell, hold, and convey real and personal property." "The CRA applies to a broader range of parties in that it does not include the exemptions contained in the $\mathrm{FHA}^{+{ }^{46}}$ However, the CRA may also require proof of intentional or purposeful discrimination to establish a prima facie case, unlike the FHA."

42 Id.

43 Act of April 9, 1866, 14 Stat 27, codified in part at 42 USC $\$ 1982$ (1994).

44 The CRA prohibits denial of the opportunity to purchase a given home based solely on race. Hurd v Hodge, 334 US 24, 34 (1948) (holding that enforcement of racially restrictive covenants denies black purchasers "the same right 'as is enjoyed by white citizens ... to inherit, purchase, lease, sell, hold, and convey real and personal property," and, as such, violates the CRA) (quoting the CRA). See also Jones $v$ Alfred H. Mayer Co, 392 US 409, 413 (1968) (noting that the CRA bars racial discrimination, both private and public, in the sale or rental of housing). For a discussion of the revival of Section 1982, see Geri J. Yonover, Comment, Dead End Street: Discrimination, the Thirteenth Amendment, and Section 1982: City of Memphis v. Greene, 451 U.S. 100 (1981), 58 Chi Kent L Rev 873, 875-76 (1982).

4542 USC $\$ 1982$.

46 See Jones, 392 US at 413 (noting that the 1866 Civil Rights Act prohibits all racial discrimination, both public and private, in the sale or rental of housing). Unlike the CRA, Section 3603(b)(1)-(2) of the FHA provides a limited exemption for "any single-family house sold or rented by an owner" or "rooms or units in dwellings containing living quarters occupied or intended to be occupied by no more than four families living independently of each other, if the owner actually maintains and occupies one of such living quarters as his residence." 42 USC $\$ 3603(\mathrm{~b})$. Similarly, the FHA provides a limited exception for religious organizations and private clubs, and provides an exemption to prohibitions on discrimination based on familial status for housing for older persons. 42 USC \$ 3607.

Unlike the FHA, the CRA contains no limitation on punitive damages. See Phillips $v$ Hunter Trails Community Association, 685 F2d 184, 191 (7th Cir 1982) (holding that punitive damages under Section 1982 are unlimited, even if the FHA is also violated); Davis $v$ The Mansards, 597 F Supp 334, 347 (N D Ind 1984) (evaluating punitive damage amount without discussing a statutory limit). See also Richard A. Di Lisi, Note, Justice White Mixes More Than Just Color to Create a New Shade of Racial Protection, 39 Case W Res L Rev 1343, 1364 (1989) ("Section 1982 is [ ] considered substantially broader in its protection than the Fair Housing Act of 1968.").

47 Whether discriminatory intent (specifically, racial animus) is an element of a prima facie Section 1982 claim remains unclear. Compare City of Memphis v Greene, 451 US 100, 131, 135 (1981) (White concurring) ("Purposeful racial discrimination is quite clearly the focus" of Section 1982 and therefore a prima facie case requires a showing of racial animus.), with subsequent federal district court decisions such as Davis, 597 F Supp at 345 ("A prima facie case of housing discrimination under both the Fair Housing Act and the 1866 Civil Rights Act consists of the [same elements]."), "and Normal v Saint Louis Concrete Pipe Co, 447 F Supp 624, 629 (E D Mo 1978) ("[T]he effect, rather than the motivation, of a housing practice is the touchstone in examining the conduct of the defendants" under both the FHA and the CRA.), and Smith v Anchor Building Corp, 536 F2d 231, 233 (8th Cir 1976) ("Effect, not motivation, is the touchstone" of both the FHA and section 1982.). 
2. The reporting requirement could prevent landlords from evading the FHA and CRA.

The ECOA states, "Within thirty days (or such longer reasonable time as specified in regulations of the Board [of Governors of the Federal Reserve] for any class of credit transaction) after receipt of a completed application for credit, a creditor shall notify the applicant of its action on the application." More importantly, an "applicant against whom adverse action is taken" is "entitled to a statement of reasons for such action from the creditor." "This statement of reasons must be specific enough to notify the consumer of the exact deficiencies in his credit application and how he could have met the creditor's terms. ${ }^{\text {so }}$

Without the ECOA's reporting requirement, a landlord could discriminate against applicants of a certain race and hide behind the excuse of bad credit without even running the credit check. If the ECOA applied to leases of real property, it would force landlords to be more accountable by requiring them to explain the exact reasons for their adverse action. ${ }^{\text {s1 }}$ In this way, the ECOA could add teeth to both the FHA ${ }^{52}$ and the CRA by preventing landlords from using the pretext of bad credit to disguise discrimination. ${ }^{\text {s3 }}$

In addition, the ECOA's reporting requirement would provide tenants with useful information needed to combat discrimination through lawsuits under the FHA and CRA. ${ }^{.4}$ Such information might not other-

4815 USC $\$ 1691(d)(1)$.

4915 USC $\$ 1691(d)(2)$.

50 15 USC $\$ 1691$ (d)(3) ("A statement of reasons meets the requirements of this section only if it contains the specific reasons for the adverse action taken.") (emphasis added). See Fischl $v$ General Motors Acceptance Corp, 708 F2d 143, 148 (5th Cir 1983) (holding that "credit references are insufficient" does not fulfill the notice requirement because it does not provide enough information for the consumer to remedy the problem); Carroll v Exxon Co,434 F Supp 557,562 (E D La 1977) (holding that the statement "Credit Bureau which had been contacted could furnish little or no definitive information" regarding the applicant's credit history did not fulfill the notice requirement).

51 Effective enforcement of the FHA is particularly important if we take congressional intent and the antidiscriminatory purpose of the FHA seriously. See Ware, 7 Admin L J Am U at 118 (cited in note 7) ("If housing patterns are the result of choice without respect to race, a different and better future will result. Congress recognized this when it enacted the original Fair Housing Act in 1968 .... When housing providers become aware of the severe economic consequences of their unlawful conduct, they will have a considerable incentive to eliminate discriminatory practices. Effective enforcement is essential to obtain the result Congress intended.").

5242 USC $\$ \$ 3601-3619$.

53 The potential of the ECOA to reduce housing discrimination by preventing landlords from dodging FHA claims distinguishes ECOA application to residential leases from application to commercial leases or leases for the sale of goods. More specifically, the substantive evils caused by housing discrimination might be more significant than the harms of discrimination in other economic transactions. For this reason, society has more to potentially gain from improved FHA enforcement. See Ware, 7 Admin L J Am U at 117 (cited in note 7) ("The elimination of segregated housing patterns would ameliorate many of the vexing problems of race relations that confront this nation.").

54 See Keest, 989 PLI/Corp at 571 (cited in note 18) (Credit discrimination statutes such as the ECOA might be "[a] [s]leeping [g]iant" providing "[f]ar-[r]eaching [r]emedies"). The ECOA is likely to be increasingly important for a variety of reasons. First, the number of cases brought under the 
wise be accessible, because the ECOA is the only statute ${ }^{55}$ mandating disclosure of the specific reasons for a landlord's adverse action when he rejects an applicant based on the applicant's credit report. ECOAmandated disclosure could provide plaintiffs with information relevant to their prima facie case and the landlord's affirmative defense. First, disclosure of the reasons a plaintiff's credit report was insufficient may help the plaintiff determine whether she has a viable claim in the first instance. A prima facie case under the FHA requires an initial showing that the plaintiff is a member of a statutorily protected class otherwise qualified to rent a given dwelling. ${ }^{56}$ ECOA-mandated disclosure of the specific reasons why a plaintiff's credit report was deemed deficient by the landlord would inform the plaintiff whether she was "otherwise qualified" to rent the unit, or whether the plaintiff genuinely failed to meet some legitimate nondiscriminatory "creditworthiness" standard established by the landlord. In other words, the reporting requirement would help determine whether the poor credit rating was just a pretextual justification to deny the lease, the real reason presumably being the applicant's race or some other impermissible categorization.

ECOA is increasing, because consumer attorneys are just beginning to see credit discrimination statutes as an avenue to prosecute a host of abusive practices by creditors. Id at 572 . Furthermore, despite giving short shrift to the substantive antidiscrimination provisions of the ECOA, see Ian Ayres, Fair Driving: Gender and Race Discrimination in Retail Car Negotiations, 104 Harv L Rev 817 (1991) (noting that the antidiscrimination legislation is underenforced in areas of consumer lending other than residential mortgages), the federal agencies charged with enforcing the ECOA have recently begun to enforce the statute more vigorously. See Mahoney, 47 Emory L J at 411-12 (cited in note 38). This heightened enforcement of the ECOA, combined with renewed interest in FHA prosecution, see id (noting that the DOJ and HUD have, in the last several years, adopted an "aggressive approach" to enforcement of the FHA), is particularly salient given that the focus of this Comment is on the interaction of the two statutes and the ways in which the reporting requirement of the ECOA might advantage private plaintiffs suing under the FHA.

While one could argue that current substantial compliance with the terms of the ECOA proves that more vigorous enforcement holds limited potential for change, this claim is likely wrong. First, the potential to apply the Act to a new class of defendants means that even if creditors currently comply, this group of complying creditors might not include landlords. Second, while the reporting requirement of the ECOA by itself is not likely to result in significant change, the information provided by ECOA-mandated disclosure is significant. It will provide plaintiffs with crucial ammunition when attempting to counter landlord circumvention of statutorily granted rights proscribed elsewhere-the FHA and CRA being the two clearest examples. Third, despite the FRB's reluctance to initiate actions for ECOA violations, see Vincent Di Lorenzo, Legislative Heart and Phase Transitions: An Exploratory Study of Congress and Minority Interests, 38 Wm \& Mary L Rev 1729, 1779 (1997) ("Federal agencies have infrequently initiated fair lending actions alleging violations of the FHA/ECOA."), substantial evidence of creditor noncompliance exists. See, for example, Keest, 989 PLI/Corp at 572 (stating that there is evidence of creditors who fail to comply with the ECOA's reporting requirement).

55 While the Fair Credit Reporting Act requires creditors to provide consumers with notification of an adverse action, 15 USC $\S 1681 \mathrm{~m}$, only the ECOA requires creditors to provide disappointed applicants with the "specific reasons for [the] adverse action." Fischl, 708 F2d at 147 (emphasis added); 15 USC $\$ 1691$ (d)(3). See also note 32 and accompanying text.

56 See note 40 and accompanying text. 
Second, ECOA-mandated disclosure could help plaintiffs determine whether the landlord's justification for denying the lease is legitimate or pretextual. ${ }^{\text {s7 }}$ ECOA disclosure would require landlords seeking to deny tenants' applications based on deficient credit to inform tenants about the specific deficiencies of their credit reports. Such disclosure would inform the plaintiff-tenant about the strength and validity of the landlord's insufficient credit defense. Information about the landlord's claim that the plaintiff has insufficient credit is particularly critical to the plaintiff arguing that the landlord's insufficient credit defense is mere pretext. The fact that a pretext check can be met with a showing of objective evidence indicating that the plaintiff was an unsuitable candidate for a lease ${ }^{\text {ss }} \mathrm{dem}$ onstrates that information elicited by the ECOA is relevant to the strength of the landlord's affirmative defense. If the landlord has objective evidence that a specific element of the plaintiff's credit report did not meet his lawful criteria, such evidence is likely to defeat the plaintiff's case. The ECOA could place the burden of disclosure on the landlord thereby giving the would-be plaintiff a valuable source of informationwhether the landlord has a viable affirmative defense or is simply trying to evade the FHA with a pretextual "bad credit" excuse.

ECOA-mandated disclosure could prove to be even more critical for plaintiffs suing under the CRA. While the CRA does not contain many of the exceptions found in the FHA, ${ }^{s 9}$ it arguably requires a showing of intentional or purposeful discrimination. ${ }^{60}$ It may not be enough, under the CRA, that the plaintiff is a member of a protected class and was denied a lease. ${ }^{61}$ Therefore, information elicited by the ECOA could prove critical for the plaintiff suing under the CRA. If landlords are forced to provide applicants with the specific reasons their credit report was deficient (assuming the applicant is denied based on a bad credit report), then the would-be tenant will possess crucial information-whether the landlord's objections to the applicant's credit report appear reasonableneeded to decide whether to bring a lawsuit. Arguably, in a world where the landlord does not have to provide such information, the landlord can use insufficient credit as a pretext for all sorts of prohibited discrimination (race, sex, marital status, and so on) by claiming the denial is based on the applicant's credit report but leaving the tenant, often with defi-

57 See Part I.C.1 (discussing the mandates of the FHA).

58 Although the court may be skeptical of a defendant's subjective reasons for denying the plaintiff's application, "objective evidence indicating that truth lies behind his assertions of nondiscriminatory conduct" may pass the FHA's pretext check and result in a verdict for the defendant. See, for example, Soules v United States Department of Housing \& Urban Development, 967 F2d 817, 822 (2d Cir 1992).

59 See note 46.

60 See note 47.

61 See note 47. 
cient resources and expertise, in the dark as to exactly what was insufficient about his credit.

\section{APPLICATION OFTHE EQUAL CREDIT OPPORTUNITY ACT TO LEASES}

The scope of the ECOA's protections and prohibitions appears broad. With certain limited exceptions enumerated in the text and implementing regulations, any applicant for credit may sue a creditor for violating the terms of the Act. It is unclear, however, whether ECOA prohibitions apply to landlords leasing residential property. ${ }^{64}$ The ECOA's reporting requirement applies to "creditors" receiving "application[s] for credit." "Thus, the ECOA applies to landlords leasing property if, under the terms of the ECOA, a landlord is a "creditor." This turns on whether a lease constitutes deferred payment of debt, the necessary element of a credit transaction under the ECOA. This Part explores the text, agency interpretation, and case law surrounding the ECOA to determine whether any of these sources provide a dispositive answer to this question.

A. The Text of the Act

While there is often dispute over the weight that one should give to the myriad sources available to ascertain the meaning of a statute, few would disagree that the starting point is the text. ${ }^{65}$ The ECOA's reporting

62 It is possible, of course, that legal reforms making it more difficult for landlords to use poor credit as a pretext for discrimination will simply cause landlords to shift to other pretextual justifications. Not all landlords will shift, however, and strengthening protections against discrimination would nevertheless be justified, since application of the ECOA will raise the costs of discrimination for those who continue to discriminate.

63 See 12 CFR $\$ 202.1$ ("The purpose of this regulation is to promote the availability of credit to all creditworthy applicants without regard to [prohibited factors]."). See also Brothers v First Leasing, 724 F2d 789,793-94 (9th Cir 1984) (noting the "overriding national policy against discrimination that underlies the Act" and claiming "[t]he ECOA is simply one more tool to be used in our vigorous national effort to eradicate invidious discrimination").

64 For a limited discussion of the ECOA's application to residential leases, see Kim JohnsonSpratt, Note, Housing Discrimination and Source of Income: A Tenant's Losing Battle, 32 Ind L Rev 457, 462, 465 (1999) (arguing that "[t]enants receiving Section 8 [of the Low-Income Housing Act] assistance or TANF [Temporary Assistance for Needy Families] . . . can find limited protection under the Equal Credit Opportunity Act" but concluding that the ECOA's protections are "not broad enough to deal with the private rental housing sector").

While the ECOA clearly prohibits discrimination based on "receipt of public assistance," 15 USC $\$ 1691$ (a)(2), it does not explicitly address whether its protections are triggered in the context of a lease application. At present, however, the FHA and the ECOA "usually are linked only in cases against lenders or other creditors involving residential real estate, usually mortgages" and "FHA claims routinely are joined with claims under the ECOA in any case involving a 'creditor' as the term

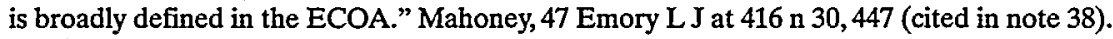

6515 USC \& 1691(d).

66 See, for example, Liberty Leasing Co v Machamer, 6 F Supp 2d 714, 716 (S D Ohio 1998) (beginning ECOA analysis by quoting the text of the act). See also Estate of Cowart $v$ Nicklos Drill- 
requirement applies to "creditors" receiving "application[s] for credit." The ECOA defines "creditor" as "any person who regularly extends, renews, or continues credit; any person who regularly arranges for the extension, renewal, or continuation of credit; or any assignee of an original creditor who participates in the decision to extend, renew, or continue credit."

More centrally, the statute defines "credit" as "the right granted by a creditor to a debtor to defer payment of debt or to incur debts and defer its payment or to purchase property or services and defer payment therefor." ${ }^{\circ}$ This definition is central to the Comment-whether the ECOA applies to leases turns on whether a lease falls within this definition. Thus, by the wording of the statute, a lease is "credit" only if it involves "defer[ed] payment of debt."

The preceding argument must be weighed against the fact that Congress may have struck the appropriate balance by excluding leases from ECOA coverage. Because the text of the ECOA makes no mention of leases when it speaks of credit transactions, we might think the act was not intended to include leases. If Congress intended to cover such a broad category of transactions, it would have used a term more explicit than "credit." In other instances, Congress has regulated leases by explicitly including them within a legislative scheme. ${ }^{n}$ Furthermore, leases are often considered distinct from credit, ${ }^{2}$ even mutually exclusive with credit, ${ }^{73}$ thus rendering an interpretation that automatically folds all leases into the ECOA's definition of credit questionable.

ing Co, 505 US 469, 475 (1992) ("In a statutory construction case, the beginning point must be the language of the statute, and when a statute speaks with clarity to an issue judicial inquiry into the statute's meaning, in all but the most extraordinary circumstance, is finished."); Chevron USA, Inc v National Resources Defense Council, Inc, 467 US 837, 842-43 (1984) ("Statutory construction begins and ends with the text of a statute if the meaning of that text is clear."). For arguments in favor of text as the starting point (and ending point) of statutory interpretation, see Antonin Scalia, A Matter of Interpretation: Federal Courts and the Law 16, 18, 29-37 (Princeton 1997) (Amy Gutmann, ed) (stating that one "generally accepted concrete rule[] of statutory construction ... [is] that when the text of a statute is clear, that is the end of the matter"); Frank H. Easterbrook, Legal Interpretation and the Power of the Judiciary, 7 Harv J L \& Pub Pol 87 (1984); Frank H. Easterbrook, Statutes' Domains, 50 U Chi L Rev 533 (1983).

6715 USC $\$ 1691 \mathrm{a}(\mathrm{e})$. Commentators regard the ECOA's definition of "creditor" as broad. See, for example, Mahoney, 47 Emory L J at 447 (cited in note 38).

6815 USC \& $1691 \mathrm{a}(\mathrm{d})$.

69 Id.

70 See Brothers $v$ First Leasing, 724 F2d 789, 798 (9th Cir 1984) (Canby dissenting) (noting that while applying the ECOA to leases might advance the highly desirable goal of ending discrimination, it is "impossible to accept the proposition that Congress, by its silence in passing the Consumer Leasing Act or amending the Equal Credit Opportunity Act in 1976, somehow expanded the latter Act to a coverage far beyond that accorded to leases under any provisions it had thus far enacted").

71 See, for example, 15 USC \$ 1667 (1994) (Governing "consumer leases" explicitly).

72 See note 64.

73 See text accompanying note 126. 
The text is not, however, dispositive of whether leases should categorically be defined as credit, ${ }^{74}$ as is amply demonstrated by the conflicting case law concerning attempts to answer this very question. ${ }^{35}$ While the ECOA's definition of credit is clear, whether, or to what extent, it includes leases is ambiguous.

\section{B. Agency Interpretation}

The FRB is required to promulgate implementing regulations that interpret and give effect to the ECOA. ${ }^{76}$ Both the original ECOA and the 1976 Amendments are implemented by Regulation B, ${ }^{n}$ first adopted by the FRB in 1977. While the weight such agency interpretation should carry is unsettled, agency interpretation is clearly relevant. ${ }^{78}$

74 A debate over this same issue-the definition of credit and its intersection with leases-exists in the context of the sale of goods. See, for example, John D. Ayer, On the Vacuity of the Sale/Lease Distinction, 68 Iowa L Rev 667 (1983) (arguing that there is no stable distinction between lease and sale). See also Peter F. Coogan, Is There a Difference Between a Long-Term Lease and an Installment Sale of Personal Property? 56 NYU L Rev 1036 (1981) (arguing that the long-term lease/installment sale distinction should still be drawn, albeit in fewer contexts).

The debate over whether a given transaction falls within the scope of UCC Article 9 and therefore can invoke its consumer protections is similar to the ECOA debate. To benefit from UCC Article 9, consumers attempt to characterize transactions as sales subject to security interest rather than leases since Article 9 covers security interests, not leases. See Eligio Pimentel, Renting-to-Own: $E x$ ploitation or Market Efficiency?, 13 L \& Ineq J 369, 375-76 (1995) (discussing the lease versus security interest debate that arises when consumers attempt to invoke Article 9). The 1990 UCC revisions resolve the security interest versus lease categorization based on the objective characteristics of the transaction, not the subjective intent of the contracting parties. The drafters of the revisions failed to eliminate all references to the subjective intent of the parties. See Pimentel, $13 \mathrm{~L} \& \mathrm{Ineq} \mathrm{J}$ at 376, citing UCC \$ 1-201, Official Comment 37 (1994) (noting that "a transaction creates a security interest if the lessee has an obligation to continue paying consideration for the term of the lease, if the obligation is not terminable by the lessee ... and if one of four additional [economic] tests is met").

Even if the UCC could reasonably be applied by analogy, such arguments are of questionable relevance because they center on the UCC's definitions which do not intersect with the definition of "credit" contained in the ECOA. See UCC § 1-201(37) (1995) (defining "security interest" and recognizing the distinction between lease and credit/sale). But see Ayer, 68 Iowa L Rev at 668 n 10 (noting that "most of the examples [in the article] concern personal property because most saleflease case law involves personal property. But in principle there is no reason why the same argument [against the sale/lease distinction] cannot apply just as well to real property leasing."). Furthermore, given the confusion surrounding the UCC's definitions, it is unclear that they could be of any help. See Pimentel, $13 \mathrm{~L}$ \& Ineq J at 376 ("[C]ircumstances under which a security interest is created [under the UCC] remain ambiguous" in part because of severe definitional inconsistency between UCC \$ 1-201 and § 9-102.). Because this Comment takes the ECOA's credit definition as a given, arguments related to other ways to define the term are beyond this Comment's scope.

75 See Part II.C (discussing conflicting case law concerning whether leases constitute "credit" within the meaning of the ECOA).

7615 USC $\$ 1691 \mathrm{~b}(\mathrm{a})(1)$.

7742 Fed Reg 1242 (1977), revised by 50 Fed Reg 48018 (1985), codified at 12 CFR $\S 202$ (1999).

78 Compare Chevron USA, Inc v Natural Resources Defense Council, 467 US 837, 842-43 (1984) (holding that courts should adopt a two-step approach, asking first whether Congress specifically addressed the interpretive question and second whether the agency's interpretation is reasonable), with K Mart Corp v Cartier, Inc, 486 US 281,292-93 n 4 (1988) (limiting step one of the Chevron analysis to considering whether the statutory text specifically addresses the interpretive question 
Similar to the ECOA, Regulation B defines "creditor," in relevant part, as "a person who, in the ordinary course of business, regularly participates in the decision of whether or not to extend credit." ${ }^{\prime 79}$ Regulation B defines a "credit transaction" as "every aspect of an applicant's dealings with a creditor regarding an application for credit or an existing extension of credit (including, but not limited to, information requirements; investigation procedures; standards of creditworthiness; terms of credit; furnishing of credit information; revocation, alteration, or termination of credit; and collection procedures). ${ }^{\text {"so }}$ Unfortunately, this definition is derivative of the definition of "credit" - it focuses on the "transaction" aspect of the term "credit transaction" but fails to shed much light on the meaning of "credit."

Consistent with the text of the ECOA, Regulation B defines "credit" as "the right granted by a creditor to an applicant to defer payment of a debt, incur debt and defer its payment, or purchase property or services and defer payment therefor.," The Official Staff Commentary on Regulation B's definition of "credit" states:

Regulation $B$ covers a wider range of credit transactions than Regulation Z (Truth in Lending). For purposes of Regulation B a transaction is credit if there is a right to defer payment of a debt regardless of whether the credit is for personal or commercial purposes, the number of installments required for repayment, or whether the transaction is subject to finance charge.

Thus, both the text of the ECOA and Regulation B state that deferred payment is the essential element of "credit."

Despite this agreement on the definition of credit, the 1985 Board of Governors for the FRB has explicitly stated that the ECOA should not be construed to cover leases. In issuing its revision to Regulation $B$ under ECOA, the Board provided supplementary information concerning its interpretation of the regulation. This supplementary information is entitled to less judicial deference than an FRB regulation. ${ }^{83}$ The Board

and refusing to consider legislative history).

7912 CFR § 202.2(1).

8012 CFR § $202.2(\mathrm{~m})$.

81 12 CFR $\$ 202.2(\mathrm{j})$.

82 Official Staff Interpretation of $\$ 202.2(j)$ of Regulation B, 12 CFR $\$ 202$ Supp I.

83 Regardless of whether an official FRB interpretation is on equal footing with a regulation, supplementary information, much like a statement of purpose published at the beginning of a statute, should not be accorded the same deference as a regulation. The FRB concedes that "[ $t$ ] Staff] Commentary replaces" all previous Board interpretation of the ECOA and that "[t]he commentary is the means by which [the Board] issues official staff interpretations of Regulation B." 12 CFR § 202, Appendix D (1999). Furthermore, the Board stated that after considering application of the ECOA to leases, "no changes [to Regulation B] resulted." 12 CFR \& 202, Supplementary Information. In fact, the Board reasserted its broad definition of credit. The Board should not be able to make rules that are equally binding as regulations without actually regulating. 
of Governors noted that "the Ninth Circuit interpreted the ECOA's definition of credit too broadly when it concluded in the Brothers case ...that ... a lease is an extension of credit. The Congress has consistently viewed lease and credit transactions as distinct and mutually exclusive." ${ }^{, 4}$ Given the clear definition of credit, ${ }^{85}$ this agency interpretation, in direct response to a case suggesting that all leases are credit transactions, suggests that the Board of Governors did not think that leases could categorically be described as credit transactions, despite the statute's allinclusive language. Even if agency interpretation and congressional intent are entitled to significant deference, however, the clear text defining credit still controls. ${ }^{87}$ If under state (or federal) law a given lease transaction necessarily involves deferred payment, courts should be hardpressed to conclude such leases are not credit transactions within the scope of the ECOA.

\section{Judicial Precedent}

The relevant case law, consistent with text and agency interpretation, ${ }^{88}$ holds that deferred payment is a necessary element of "credit" according to the ECOA's definition. "The element of deferred payment appears sufficient to render a transaction "credit" under the terms of the ECOA - "any deferral of payment, such as payment for services a week after the services are provided" can categorize a transaction as "credit"

8412 CFR \& 202 Supplementary Information (1985).

85 See Brothers v First Leasing, 724 F2d 789, 793 (9th Cir 1984) (construing the "literal language of the ECOA," in light of the Act's antidiscriminatory purpose, as dispositive of the issue of whether credit transactions include leases).

86 The broad coverage of the ECOA is confirmed by the FRB's statement that "[t]he purpose of this regulation is to promote the availability of credit to all creditworthy applicants." 12 CFR $\$ 202.1(b)$ (1999). Such a broad statement of purpose seems in tension with the Board's limiting interpretation of "credit."

87 The first part of the Chevron test is to ask whether Congress specifically addressed the interpretive question. 467 US at 842 . The agency is not entitled to deference if the statutory text answers the question or the agency interpretation is not "reasonable." Id at 842-43. See also K Mart, 486 US at 292-93 \& $n 4$ (limiting the first step of the Chevron inquiry to the statutory text). We might think the Board's interpretation is unreasonable on the grounds that it fails to even consider the possible application of state law or to determine whether given leases may meet the definition of credit contained in the statute.

Furthermore, the degree of deference due to the FRB's supplementary information (which is neither part of the official staff interpretation nor the regulatory text) under Chevron is unclear even if deference to agency regulations and official interpretation is significant.

88 See Parts II.A and II.B.

89 See Williams v AT \& $T$ Wireless Services, Inc, 5 F Supp 2d 1142, 1145 (W D Wash 1998) (holding that ECOA governs sale of cellular telephone service because "the transaction involves the purchase of services and deferral of payment for those services"); Dunn v American Express Co, 529 F Supp 633, 634 (D Colo 1982) (finding that an application for an automatic teller machine card is not a credit transaction under the ECOA because there is no "right to defer the payment of any debt"); Butler v Capitol Federal Savings, 904 F. Supp 1230, 1234 (D Kan 1995) (finding that opening a savings account is not a credit transaction because it does not involve the right to defer payment of a debt). 
under the terms of the Act. ${ }^{\circ}$ Even though a lease may not primarily provide credit, any deferral is arguably sufficient to qualify a lease as credit. Regardless of whether deferred payment is sufficient to categorize a transaction as credit, it is clearly a necessary element. Transactions that do not involve any deferral of payment fall outside the scope of the ECOA's definition of credit and are thus beyond the Act's coverage.

Because the Supreme Court has not settled the issue of whether the ECOA's definition of credit encompasses residential leases, there is no clear nationwide rule governing the issue. A well developed body of case law interpreting the relevant provision of the ECOA does not exist, since "credit discrimination laws are only now beginning to be utilized aggressively" and in the 1980s "only a small number of ECOA cases were brought each year." ${ }^{\prime 91}$ Given the dearth of case law on point, ${ }^{92}$ this Comment looks to cases dealing with non-housing leases as relevant to whether housing leases ought to be considered credit under the ECOA. The case law presents examples of approaches courts have taken to the issue of leases as credit under the ECOA rather than an indicator of what the law is (given the lack of stable consistent precedent). A survey of the case law, however, yields a numeric trend in favor of categorizing leases as credit as defined by the ECOA.

1. Cases holding that the ECOA applies to leases.

The only case directly considering whether a real property lease constitutes credit (deferred payment) under the ECOA is Ferguson $v$ Park City Mobile Homes, ${ }^{93}$ a federal district court case. In Ferguson, the plaintiff sued an owner of mobile home lots who refused, allegedly in violation of the antidiscrimination provisions of the ECOA, to lease him a plot of land. The defendant moved to dismiss for failure to state a claim under the ECOA, arguing that the ECOA does not apply to leases of real property." The district court held that "[t]he language of the ECOA is certainly broad enough to cover the lease of a mobile home lot" ${ }^{\text {" }}$ given that "the term 'credit transaction,' as used in the ECOA, has always been broad enough to allow for consumer lease transactions to be included in its definition." The district court went on to state "any lease to be paid in installments is a credit transaction, since the willingness of

90 Keest, 989 PLI/Corp at 575 (cited in note 18).

91 Id at 572.

92 See Ferguson v Park City Mobile Homes, 1989 US Dist LEXIS 11010, *5 (N D Ill) (noting that there exists "a dearth of authority regarding whether a lease transaction for a mobile home lot was intended to be subsumed by the ECOA's definition of credit").

931989 US Dist LEXIS 11010 (N D Ill) (applying Illinois law).

94 Id at $* 2-4$.

95 Id at *2.

96 Id at *6-7. 
the lessor to defer payments over the life of the lease depends upon the perceived creditworthiness of the lessee." courts should consider almost any property lease a credit transaction because periodic payments throughout the duration of the lease are an element common to most leases."

Courts have also held leases of personal property to be credit transactions. The Ninth Circuit, in Brothers $v$ First Leasing, ${ }^{9}$ ruled that the ECOA applies in the context of automobile leases. The Ninth Circuit reasoned that any lease falls within the ECOA's definition of "credit" as "defer[red] payment of debt" because a lease involves the exchange of property in return for payment made in installments. ${ }^{100}$ Adopting the Ninth Circuit's logic, we would similarly categorize all housing leases as credit because they too involve the exchange of property (or the right to possess the dwelling in the case of the residential lease) in return for payment made in installments. ${ }^{101}$

Most recently, a district court in Williams $v A T \& T$ Wireless Services, Inc ${ }^{1,2}$ held that a consumer's application to purchase cellular telephone service was a "credit transaction" under the ECOA because "the transaction involves the purchase of services and deferral of payment for those services." ${ }^{\text {"103 }}$ Although this case does not address the issue of whether a lease is a credit transaction, it does support a significantly widened definition of credit by eliminating the requirement that the transaction involve deferred debt.

The Williams court distinguished Shaumyan $v$ Sidetex $\mathrm{Co}^{104}$ a Second Circuit decision, which held that a transaction involving payments "substantially contemporaneous" with performance is not a credit transaction, ${ }^{\text {lus }}$ on two grounds. ${ }^{1.6}$ First, the plaintiffs in Shaumyan prepaid for the services they received. ${ }^{107}$ Second, the transaction in Shaumyan, unlike the transaction in Williams, "did not involve an assessment of the creditwor-

97 Id at *8. While this language comes from the court's discussion of the FCRA, the court explicitly broadened its claim by stating leases paid in installments are credit "[a]s an economic matter." Id.

98 Because residential leases are often for a one-year term and because a tenant is rarely willing or able to pay for the entire year's rent in one lump sum, the lease most often provides for lease payments on a monthly basis. See, for example, Sanford Kahn, American Legal Forms No 104, Chicago Apartment Lease (unfurnished) (1981, revised Jan 1995), a standard form lease with a field for "monthly rent."

99724 F2d 789, 793 (9th Cir 1984).

100 Id at $792-93 \mathrm{n} 8$.

$101 \mathrm{Id}$.

1025 F Supp 2d 1142 (W D Wash 1998).

103 Id at 1145.

$104900 \mathrm{~F} 2 \mathrm{~d} 16$ (2d Cir 1990).

105 Id at 18.

1065 F Supp 2d at 1146.

$107900 \mathrm{~F} 2 \mathrm{~d}$ at 17. 
thiness of the plaintiffs." ${ }^{108}$ According to the district court in Williams, deferred payment (even if not "debt") and an assessment of the applicant's creditworthiness both act as plus factors in favor of categorizing a transaction as "credit" under the ECOA. On this view, a housing lease appears to be a credit transaction-tenants lease property for a fixed term, ${ }^{109}$ deferring payment for the entire term by making payments in installments, and landlords, especially those utilizing credit reports, make an assessment of applicants' creditworthiness.

\section{Cases holding that the ECOA does not apply to leases.}

While the trend seems to favor categorizing most leases as credit transactions within the reach of the ECOA, the reasoning in cases such as Brothers ${ }^{110}$ and Ferguson ${ }^{111}$ has, on occasion, been sharply criticized. Liberty Leasing Co v Machamer, ${ }^{112}$ a district court decision, is a good example. The district court in Liberty Leasing held that a lease is not covered by the ECOA because it is a transaction involving payment for contemporaneous use, not a "deferred debt."113 The case involved a defendant who defaulted on a lease for automobile service equipment. ${ }^{114}$ When the plaintiff sued to recover the outstanding balance on the lease, the defendant argued the lease was void under the ECOA. ${ }^{115}$ The validity of this defense turned on whether the ECOA applied to leases in the first place. $^{\text {1' }}$

The district court explicitly rejected the Ninth Circuit's holding in Brothers ${ }^{117}$ that, as a matter of law, a lease obligation was a "credit" transaction as defined by the ECOA. ${ }^{118}$ Rather, the district court looked to the terms of the lease agreement to determine whether the lease was a deferred debt within the meaning of the ECOA or payment in advance for contemporaneous use. ${ }^{119}$ The district court reasoned that a lease containing terms allowing the lessee to surrender possession and avoid liability for the entire outstanding balance of the lease was not a credit transaction since payment is not being deferred if surrender of the equipment extinguishes liability under the lease agreement. ${ }^{120}$ The district court ex-

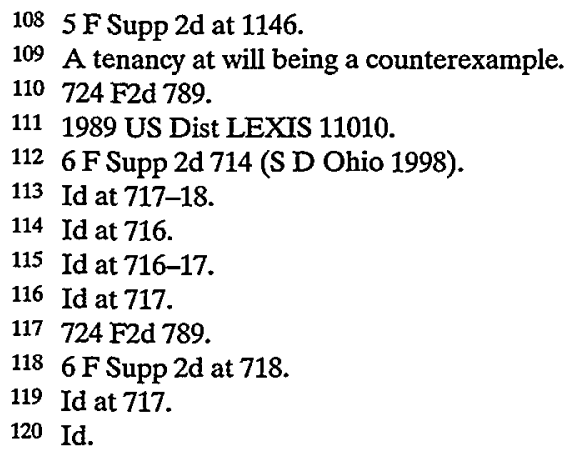


plained: "The relevant inquiry is whether the incremental payments constitute a contemporaneous exchange of consideration for the possession of the leased goods." ${ }^{121}$ Where the leasing agreement, or applicable law, provides for such a contemporaneous exchange, then the lessee cannot be said to "defer [the] payment of [a] debt" within the meaning of the ECOA.

The district court further argued that the Uniform Commercial Code prohibits the lessor from maintaining an action for the full amount of unpaid rent when the lessee has surrendered possession-evidence that, legally, an equipment lease could not be a deferred debt within the meaning of the ECOA. ${ }^{123}$ On this logic, a property lease is a credit transaction only to the extent that surrender of the leased property does not extinguish the parties' liability under the lease. In other words, it is not the lease qua lease that controls the categorization, it is the surrounding law defining the terms of the lease that determines whether the lease can and does take on the necessary deferred debt characteristic.

The Liberty Leasing court also criticized the reasoning in Ferguson ${ }^{124}$ for overlooking the final rule promulgated by the 1985 Board of Governors for the FRB which explicitly states that the ECOA should not be construed to cover leases. ${ }^{125}$ The court noted:

[T] he Board of Governors expressly rejected the holding in Brothers that [the] ECOA was enacted to encompass lease transactions. In issuing its interpretation of, and revisions to, Regulation B under ECOA, which includes one of the definitions of "credit," the Board of Governors said [that] ... "the Ninth Circuit interpreted the ECOA's definition of credit too broadly when it concluded in the Brothers case that ... a lease is an extension of credit. The Congress has consistently viewed lease and credit transactions as distinct and mutually exclusive."

Because an agency's construction of regulations it is charged with enforcing is entitled to judicial deference, ${ }^{127}$ the district court in Liberty Leasing concurred with the Board of Governors and held that the ECOA does not apply to lease transactions. ${ }^{123}$ This reasoning, however, overlooks the definition of credit. Some leases do include deferred debt. Thus, following the reasoning of the Board of Governors without individualized

121 Id (citations omitted).

122 Id.

123 Id at 717-18.

1241989 US Dist LEXIS 11010.

1256 F Supp 2d at 718-19. See Part II.B.

126 Id at 719, quoting Regulation B, 12 CFR $\$ 202$ Supplementary Information. See text accompanying note 84 .

127 See note 78 (discussing Chevron deference).

128 See Part II.B. 
consideration leads to conflicts with the text of the statute. ${ }^{129}$ Indeed, the Liberty Leasing court implicitly acknowledged the validity of individualized lease categorization. If the FRB's position that leases are categorically excluded from ECOA coverage was controlling, then the court would never have looked to the specific terms of the lease.

Finally, when analyzing the judicial dissensus on the applicability of the ECOA to leases, it is important to consider the timing of the decisions. Given the dearth of precedent, this Comment treats cases spanning the last two decades as relevant. While one might be tempted to explain the drastically different outcomes based on intervening FRB commentary interpreting the ECOA's definition of credit, ${ }^{13 n}$ the only regulation and accompanying commentary addressing the interpretation of "credit" came after Brothers, but before Williams and Ferguson-all of which held that credit includes leases under the ECOA. While relevant commentary interpreting the ECOA plays a strong role in the Liberty Leasing opinion, ${ }^{131}$ it does not fully explain the court's divergence from precedent; the rationale in cases such as Williams and Ferguson remained consistent with Brothers despite the intervening FRB commentary.

\section{RESOLVING THE STATUTORY INTERPRETATION DILEMMA}

In the context of real property leases, the real question is whether relevant mandatory laws permit (or require) the lease to take on the characteristic of deferred payment. From the landlord's perspective, a lease, regardless of duration, is not an extension of credit so long as the landlord can terminate the lease immediately upon non-payment by the tenant. In this sense, the tenant making periodic payments owes no debt to the landlord because the tenant has nothing more than the right to possess the property for the time period for which she has already paid. In contrast, if the landlord cannot force the tenant to surrender possession upon non-payment (which is the case in many jurisdictions ${ }^{132}$ ) then the lease resembles credit to the extent that the lease agreement, as augmented by state law, gives the tenant a legal right to possess the property for a period beyond which she has paid. This is the element of deferred payment necessary to characterize a lease as credit.

The best answer to the question of whether a lease transaction constitutes credit (that is, whether the lease involves deferred payment of debt) lies in the specific terms of the lease agreement. Similar to the approach applied to the lease of goods in Liberty Leasing, ${ }^{133}$ courts should

129 See note 78.

130 See Part II.B. See also the Brothers rationale discussed in Part II.C.1.

131 See text accompanying note 126.

132 See Part III.B.

133 See Part II.C.2. The Liberty Leasing court looked to the UCC as part of the relevant surrounding body of law to characterize a lease of goods. 6 F Supp $2 d$ at 717-18. Similarly, courts should 
look at the text of the lease, as modified by any mandatory ${ }^{134}$ state (or federal) laws limiting the parties' ability to contract, when determining whether a housing lease constitutes credit."

A determination focusing on the terms (both implicit and explicit) of the housing lease will help to more accurately determine whether the lease constitutes "credit" under the ECOA.

\section{A. General Categorizations Are Overinclusive}

Courts should use state law controlling the terms of the lease when evaluating whether the lease constitutes "credit" as defined by the ECOA. The reasoning in cases such as Brothers ${ }^{136}$ and Ferguson ${ }^{137}$ oversimplifies the inquiry surrounding the scope of the ECOA. ${ }^{138}$ Mere payment in the form of installments does not render a lease a credit transaction unless the payments are made for a good or service already provided. Not all installment payments are deferred payments of debt. Rentto-own agreements ${ }^{139}$ demonstrate this point. Rent-to-own contracts, in which an individual rents a product, pays in installments and eventually comes to own the product if a sufficient number of payments are made, ${ }^{\mathrm{j}}$ are traditionally considered lease transactions, not credit, despite the fact that payments are made in installments. ${ }^{141}$

look to relevant landlord-tenant law to characterize residential leases.

134 Mandatory rules (laws), which are not waivable by the parties, should be distinguished from default rules that the parties may contract around. These mandatory rules are as much a part of the lease as the explicit terms of the lease agreement.

135 FRB Commentary on the intersection between the ECOA and state law notes that the Act "alters, affects, or preempts only those state laws that are inconsistent with the act." 12 CFR $\$ 202.11$. This provision does not control the issue of whether state laws constructing leases are relevant to interpreting the ECOA because if state laws are relevant in this context, then they define the scope of the Act as it applies to credit. In other words, if state laws requiring that leases involve deferred payment expand the ECOA's scope, they could not be "inconsistent with the requirements of the Act." Id.

136724 F2d 789.

1371989 US Dist LEXIS 11010.

138 See text accompanying note 99. See also Brothers, 724 F2d at 797 (Canby dissenting) (arguing that the majority opinion cannot be cabined and that "[i]f a lease is a 'credit transaction,' then every lease, whether of personal property or real estate ... [is] covered by the Equal Credit Opportunity Act. It is true that the majority has not said that such an expansion of coverage will follow from their decision, but it certainly is compelled by its rationale.").

139 For a general discussion of the economics of rent-to-own agreements, see Pimentel, $13 \mathrm{~L}$ \& Ineq $\mathrm{J}$ at 369 (cited in note 74 ).

140 See James P.Nehf, Effective Regulation of Rent-to-Own Contracts, 52 Ohio St L J 751,751-57 (1991). Rent to own contracts are also known as "lease purchases."

141 See Pimentel, 13 L \& Ineq J at 370-71 (cited in note 74) (stating that most jurisdictions characterize rent-to-own contracts as leases, thereby allowing such contracts to evade most consumer protection laws). But see Miller v Colortyme, Inc, 518 NW2d 544, 548 (Minn 1994) (holding that rentto-own contracts are credit transactions "because buyers of goods are not required to make full payment upon acquiring possession but are allowed to pay for goods sold over time").

The argument that characterizing rent-to-own contracts as leases allows sellers to evade consumer protection laws and take advantage of unwitting consumers is similar to the argument one 
The rent-to-own example illustrates the overinclusiveness of the Brothers argument; installment payments do not turn a lease into a credit transaction when the necessary element of deferred payment of debt is missing. ${ }^{142}$ An additional element, that the lessee possess more than what he pays for (the "debt" of deferred payment of debt), is necessary to make a lease paid in installments a credit transaction. In other words, a lease that is paid in installments, where the installment payments are merely payments for contemporaneous use of the good and nothing more, is not a credit transaction because the lessor is only providing the lessee with the right to enjoy that which he has paid for to-date. ${ }^{143}$

The argument in Ferguson, that a lease is a credit transaction if it "depends upon the perceived creditworthiness of the lessee," overinclusive in the sense that it considers any transaction in which the lessor is concerned about the creditworthiness of the lessee to be a credit transaction. While a concern for creditworthiness often coincides with a credit transaction, it is not a sufficient characteristic to make a transaction credit. To hold otherwise would allow the subjective intent of the parties to control the legal definition of the transaction without regard for the objective nature of the relevant agreement. Furthermore, it would create a situation in which a sale clearly involving no credit, like the purchase of a good or real property with payment in cash, would constitute a credit transaction based solely on the background worries of one of the parties about the creditworthiness of the other.

Future courts should avoid the general categorizations made in cases such as Brothers and instead opt for an analysis focusing on the mandatory law governing each lease, as well as on the explicit terms of the lease. Courts should analyze the lease based on its specific terms in order to determine whether the lessee has been allowed to defer payment to the lessor for possession of the property beyond that which the lessee has already paid for.

Categorical determinations concerning the reach of the ECOA, . which assume the Act must cover all leases or no leases, fail to adequately consider the text of the Act. The ECOA's definition states that transactions involving deferred payment of debt are credit and that credit transactions are within the Act's scope. Because the ECOA sorts transactions based on a deferred credit criterion, a more nuanced analysis of

might advance with regard to characterizing housing leases as non-credit. Categorizing housing leases as non-credit allows landlords to exploit unwitting lessees lacking resources (measured in terms of time, money, interest, and ability) to determine whether denial of their rental application based on "insufficient credit" is legitimate or pretext for illegal discrimination.

142 The element of deferred payment is necessary if for no other reason than because deferred payment is the one thing that the text of the statute clearly requires.

143 In the residential context, lease payments are usually for the upcoming month - not the preceding month.

1441989 US Dist LEXIS 11010 at *8. 
leases is needed to be faithful to the text. Some leases involve deferred payment, which means they meet the ECOA's definition and should be covered by the Act. Furthermore, in order to determine which leases involve deferred payment, courts should look at the terms of the lease, as the label "lease" is not determinative. State laws governing the terms of leases may import elements of deferred debt into the transaction. Courts should not turn a blind eye to state law as an important source for determining whether a particular lease meets the statutory definition of credit thereby bringing it within the reach of the ECOA.

\section{B. Lease Terms That Favor Categorizing the Lease as Credit: Some Housing-Lease-Specific Guidelines}

Assuming ambiguity on the issue of whether a particular lease is considered credit, ${ }^{14}$ courts should presume a given lease is or is not a credit transaction based on the categorization applicable state laws favor (or mandate). Whether a lease constitutes credit is a function of both the explicit text of the lease and of the law governing the lease.

An example of a mandatory rule that may weigh in favor of characterizing a lease as a credit transaction is the rule preventing landlords from evicting tenants upon nonpayment of rent. Eviction laws may favor classifying leases as credit in instances where state law requires a landlord to provide tenants with continued possession, even in the absence of rent payment, for a period beyond that which the tenant is required to pay in advance. ${ }^{1.45}$ In these instances, where governing state law prevents the landlord from evicting the tenant upon the tenant's failure to pay the lease installment, the lease is a credit transaction in a very real sense. Not only is the creditworthiness of the tenant a central issue in the lease transaction, ${ }^{147}$ but, more concretely, the landlord is providing the tenant

145 See cases cited in Part II.C.

146 Given that most leases require the tenant to pay prospectively for the upcoming month, one could argue that the relevant state law would have to enable the tenant to retain possession for more than a month.

In most jurisdictions, forcible entry and detainer statutes provide the tenant with a nonwaivable "right" to continue possession of the leased premises for a certain period of time, even if the tenant fails to pay rent. The right is nonwaivable in the sense that the landlord and tenant cannot contract around the statutory forcible entry and detainer procedures for eviction by permitting landlord selfhelp, for example. See 49 Am Jur 2d Landlord and Tenant \$ 997 \& n 28 (1999); McCrory v Johnson, 296 Ark 231, 755 SW2d 566, 572 (1988) (holding a lease provision "illegal and invalid.... to the extent it allowed self-help by [the] landlord"); Bass $v$ Boetel \& Co, 191 Neb 733, 217 NW2d 804, 807 (1974) (noting that "[s]elf-help, relating to the repossession of real estate, has long been contrary to the public policy of Nebraska and is not to be condoned"); Thomas v Papadelis, 16 Ohio App 3d 359, 476 NE2d 726, 728 (1984) (holding that state forcible entry and detainer statute is the exclusivemeans by which a residential landlord may recover possession).

Agreements between landlord and tenant permitting landlord self-help in the case of nonpayment of rent may be void on a public policy rationale in instances where the state law does not otherwise provide for landlord self-help. See Restatement (Second) of Property $\$ 14.2(2)$ (1977).

147 Recall that in Ferguson the creditworthiness of the applicant was a factor in categorizing a 
with a "right"148 to occupy the dwelling for a time period extending beyond the time period for which the tenant is required to pay. ${ }^{149}$ In these

lease as a credit transaction. 1989 US Dist LEXIS 11010 at *8.

148 It may be more accurate to say that the tenant has an "ability" to retain possession because the tenant's ability to retain possession is more of a negative right. We might characterize laws preventing immediate eviction as providing the tenant a right to not be removed by the landlord immediately as opposed to conferring a "right" to retain possession and simultaneously refuse to pay.

149 In most states, unlawful detainer statutes allow the delinquent tenant to retain possession of the property for a certain period after she has received notice of delinquency. If the tenant pays rent before this time period expires, the landlord may not evict the tenant. See 49 Am Jur 2d Landlord and Tenant \$ 1031 \& n 4 (1999); Greenhill v Allen, 181 Ga App 532, 352 SE2d 845, 845 (1987) (holding the tenant's late rent payment "presented a complete defense" to landlord's action for possession); Bank of Belleville v Stidimire, $119 \mathrm{Ill}$ App 3d 73, 456 NE2d 175, 178 (1983) (holding that "the tenant must be given an opportunity to pay the delinquent rent before the lease may be terminated"); Allen v First National Bank of Commerce, 440 S2d 172 (La App 1983) (affirming trial court judgment in favor of the tenant on the grounds that the delinquent rent was paid before the filing of eviction proceedings); Finley $v$ Park Ten Associates, 441 NYS2d 475, 476, 83 AD2d 537, 538 (NY App Div 1981) ("Where a summary proceeding is bottomed upon violation of a substantial covenant of the lease the proceeding may not be instituted until after the time to cure has expired."); Dang $v$ Cox Corp, 655 P2d 658,660 (Utah 1982) (concluding that the landlord's unlawful detainer claim failed because the tenant paid the delinquent rent within three days of receiving notice); Housing Authority of Everett $v$ Terry, 114 Wash 2d 558,789 P2d 745,748 (1990) (tenant must be provided with the option of complying with the terms of lease within 10 days of receiving notice or surrendering the premises).

Similarly, if the landlord fails to allow the tenant to cure a delinquent rent payment (by paying the amount due) during the statutory time period imported into the lease, then the landlord is barred from bringing an action for possession (eviction) on the basis of that default. See $49 \mathrm{Am}$ Jur 2d Landlord and Tenant $\$ 1031$ \& n 5 (1999); Norwalk Mall Venture v Mijo, Inc, 11 Conn App 360, 527 A2d 1202, 1206 (1987) ("[F]ailure of the plaintiff to allow the [tenant] defendant fifteen days to cure the default ... precluded its claim for possession on the basis of that default."); Tage II Corp v Ducas (U.S.) Realty Corp, 17 Mass App 664, 461 NE2d 1222,1225 (1984) (finding that tenant has thirty days from the date of notice to comply with the terms of the lease and thereby avoid a successful action for possession by the landlord).

Furthermore, if the delinquent tenant pays the amount due within the statutory cure period then the landlord may not evict the tenant on the basis of the previously delinquent rent. See 49 Am Jur Landlord and Tenant $\$ 1031$ \& n 7; City of New Orleans $v$ Cheramie, 509 S2d 58,61-62 (La App 1987) (affirming judgment against the landlord in an eviction proceeding when the tenant had made a "good faith effort to cure their default within $\mathbf{3 0}$ days after being given notice of default"). Even once summary eviction proceedings against the tenant have commenced, payment of the delinquent rent will often constitute a sufficient cure, thereby staying the eviction proceeding. See 49 Am Jur 2d Landlord and Tenant \$ 1031 \& n 8; In re Telephonics, Inc, 85 Bankr 312, 316 (E D Pa 1988) ("[U]nder applicable Pennsylvania law, a lease is not 'terminated' when the tenant fails to pay rent due until the tenant is physically evicted, rather than upon the entry of a judgment for possession.... a tenant retains a right to cure any rental delinquency and preserve the tenancy until the moment of actual valid and complete eviction of the tenant.") (emphasis added); Johnson v Edgewood Management Corp, 512 A2d 287, 288 (DC App 1986) (A tenant may "redeem his tenancy," even after a judgment for possession has been entered against him, by paying the delinquent rent, including interest and other costs.); Omni Quip of Jacksonville, II, Inc v Milo, Inc, 542 S2d 477, 478 (Fla App 1989) (trial court abused its discretion by granting the landlord possession without allowing the tenant to pay delinquent rent); Paul McCusker \& Associates, Inc v Omodt, 359 NW2d 747, 748 (Minn App 1985) (tenant may be granted possession and continuation of the lease by paying the landlord delinquent rent, "with interest and costs of the action," "at any time before possession has been delivered" to the landlord) (quoting Minn Stat $\S 504.02$ (1982)); French $v$ Ester, 749 SW2d 461, 462 (Mo App 1988) (Payment is a defense that is "equally available when payment is tendered after the date the judgment was originally entered by the associate circuit judge but before the trial de novo."). 
instances, the tenant is deferring payment to the landlord in the sense that the tenant pays on a monthly basis but has the ability to cease payment and retain possession beyond the month for which he has paid. This ability to maintain possession, where it is legally required, means that housing leases are credit transactions within the meaning of the ECOA; they do not involve contemporaneous payment for possession because state law requires that the lessee have the ability to maintain possession beyond the time period for which he has paid.

\section{Policy Arguments Concerning the Application of the ECOA to Leases}

\section{Arguments favoring application of the ECOA.}

Widespread housing discrimination, thoroughly documented by solid empirical evidence, ${ }^{152}$ justifies ECOA mandated disclosure in the residential lease context. Such disclosure would further the ECOA's

150 Under the Uniform Residential Landlord and Tenant Act \$ 4.201(b) (1985), the delinquent tenant has fourteen days after receiving notice from the landiord (of delinquency and intent to terminate the lease) to pay rent in order to prevent the landlord from terminating the lease agreement. When this fourteen-day grace period is imported into a lease agreement, the lease agreement appears to involve credit as the landlord has no choice but to allow the tenant to exercise her statutory right and enjoy the property for two weeks without payment in advance.

151 The obvious rejoinder to this characterization, even in states that have mandatory rules preventing immediate eviction for failure to pay rent, is that the landlord may, and often does, require a security deposit that covers the potential rent for this unpaid period in which he must wait to evict the delinquent tenant. The relevance of this argument turns on state law governing housing leases as well. For instance, is the landlord permitted to require a security deposit that is sufficient to cover the window of time in which he must wait to evict the delinquent tenant? Furthermore, may the landlord divert the delinquent tenant's security deposit to pay for the rent that the tenant has failed to pay, or must the landlord attempt to secure this payment by other means? If the security deposit serves only as security for damage to the apartment and may not be used to offset the balance owed by the tenant for unpaid rent, then it does little to undermine the characterization of the lease as credit. Of course, all of these arguments turn on the substantive content of relevant state and local law. See, for example, Chicago Municipal Code Ch 5-12-080(d) (1990) (stating that landlord must return security deposit but may deduct money for damages and unpaid rent).

Other examples of mandatory lease terms that might render a lease credit under the ECOA are statutes allowing generous repair and deduct by tenants (forcing the landlord to allow tenants to deduct rent payments). Even if such deductions turn out to be larger than needed repairs, such statutes position the landlord as a creditor in the sense that the tenant is allowed to deduct (possibly incur a debt larger than the legitimate cost of repair) and defer payment until the landlord wins a judgment stating that the deduction was exorbitant.

152 See notes 7 and 9. See also Jody David Armour, Affirmative Action: Diversity of Opinions: Hype and Reality in Affirmative Action, 68 U Colo L Rev 1173,1177-78 (1997) (describing "evidence of massive discrimination in housing markets and residential choice" and noting that undercover investigations controlling for virtually all variables other than race and ethnicity demonstrate widespread housing discrimination); Florence Wagman Roisman, Book Review, The Lessons of American Apartheid: The Necessity and Means of Promoting Residential Racial Integration, 81 Iowa L Rev 479, 496 (1995) ("HUD's 1989 National Housing Discrimination Study showed that discrimination continues to be widespread."); Douglas S. Massey and Nancy A. Denton, American Apartheid: Segregation and the Making of the Underclass 99-109 (Harvard 1993) (citing housing discrimination studies, controlling for income, confirming rampant discrimination against blacks in housing rental). 
broad anti-discriminatory aim by targeting a massive and persistent source of discrimination impacting the ECOA's protected class in a particularly destructive manner. ${ }^{1.3}$ Applying the ECOA to residential leases may specifically benefit the persons the ECOA was designed to protect, as they might be the very persons most likely to sign such leases. ${ }^{1.44}$ If the ECOA's purpose is to protect those most likely to be discriminated against when applying for credit, then housing leases that meet the ECOA's definition of credit might be a good proxy for transactions undertaken by this target population. ${ }^{155}$ The poor are more likely to resort to leases, instead of mortgages, than the rich. The sheer cost of buying a home combined with the real and perceived difficulties associated with obtaining a mortgage mean that leases might be a reasonable proxy for the less wealthy. Given that the legislative purpose of the ECOA was to protect those for whom inability to obtain credit is an acute problem, ${ }^{156}$ we might be pleased with an interpretation of the ECOA that provides yet another protection to this target population."

Application of the ECOA to housing leases would alter the quantity and quality of lawsuits brought by tenant-plaintiffs. Because disclosure would better inform tenants by providing them with the reasons their credit was insufficient, tenants would be more likely to bring meritorious lawsuits. Some tenants in the status quo who have meritorious FHA

153 See note 15 . Housing discrimination is uniquely harmful. The primary effect of housing discrimination, preventing minorities from living where they choose, see Michelle Adams, Separate and Unequal: Housing Choice, Mobility and Equalization in the Federally Subsidized Housing Program, 71 Tul L Rev 413, 427-28 (1996) (noting that "[t] he ability to choose where to live ... is linked to the idea of freedom in the American popular imagination"), is inextricably linked to a host of devastating secondary effects, such as decreased access to good schools, exposure to unclean and unsafe environmental conditions, and lack of access to employment. See Gary Orfield, Housing and the Justification of School Segregation, 143 U Pa L Rev 1397, 1401 (1995) (schools); Robert D. Bullard, Environmental Racism and "Invisible" Communities, 96 W Va L Rev 1037, 1042 (1994) (environmental hazards); William Julius Wilson, The Truly Disadvantaged: The Inner City, the Underclass, and Public Policy 42 (1987) (employment).

154 See notes 21 and 23 and accompanying text (noting that the purpose of the ECOA is to address the difficulties faced by the protected groups when applying for consumer credit).

The Board of Governors of the Federal Reserve acknowledged a similar point before denying that the ECOA applies to leases. "It seems inconsistent to allow lessors to consider marital status, sex, and other characteristics while creditors are prohibited from doing so. In addition, some lease transactions are similar in many ways to credit transactions." 12 CFR $\$ 202$ Supplementary Information (1985).

155 The court in Brothers, $724 \mathrm{~F} 2 \mathrm{~d}$ at 793, makes a similar argument, with respect to the lease of goods, claiming that "[w]e must construe the literal language of the ECOA in light of the clear, strong purpose evidenced by the Act and adopt an interpretation that will serve to effectuate that purpose."

156 See note 63 .

157 This is especially true given that the distinction between lease and credit is often arbitrary, and that we should not let the level of legal protection vary based on such an unprincipled distinction. See Ayer, 68 Iowa L Rev at 697 (cited in note 74) ("[G]iven the subtle, sometimes arbitrary distinction between lease and secured credit in our law, it simply is incomprehensible why so much is made to ride on the distinction."). 
claims - because they have, in fact, suffered discrimination - do not sue, either because they believe the landlord's insufficient credit reason, or because they lack the information to determine whether the reason is valid. ${ }^{1: 5}$ ECOA-mandated disclosure would result in an increased number of meritorious lawsuits brought by members of this group of would-be plaintiffs. Accordingly, ECOA application to housing leases would advance legitimate FHA claims that are not brought currently because of landlord circumvention that leaves tenants ill informed. Disclosure would more effectively and efficiently enforce the FHA by promoting legitimate lawsuits against discriminatory landlords.

ECOA disclosure may have the added benefit of reducing the number of ill-informed, and ultimately unsuccessful, lawsuits. Currently, some tenants, legitimately denied a lease based on their poor credit, choose to sue nonetheless, either because they do not believe the landlord's rationale-despite its accuracy-or because when faced with insufficient information to evaluate the landlord's reason, they presume that the landlord has discriminated against them. Tenants provided with the specific reasons their credit is inadequate may rationally decide to forgo a lawsuit if the objective evidence presented by the landlord indicates a low probability of success. A reduction in non-meritorious lawsuits would save time and money for landlords, tenants, and courts alike.

This potential win-win situation raises the issue of why landlords would not provide such information, even absent regulation, if it saved the cost of defending non-meritorious lawsuits. One explanation for landlord inaction is a market failure caused by incomplete informationlandlords are failing to act in their own self-interest to maximize profits because they do not know that disclosure would, on balance, be less costly than failing to give specific reasons to rejected applicants and facing more lawsuits. ${ }^{159}$

\section{Arguments against application of the ECOA.}

An argument against applying the ECOA is the landlords' compliance cost. The ECOA, unlike the FHA,${ }^{160}$ contains no exception for small landlords, and therefore, applying the ECOA to all residential leases would impose a potentially substantial reporting requirement on the

158 See discussion in Part I.C.2.

159 One might also argue that landlords, even if informed of the potential benefits of disclosure, will continue not to provide tenants with specific reasons for adverse action, because landlords may fear setting a precedent that would force them to provide such information in the future; a change in circumstances, such as increased administrative costs, could undermine the landlords' rationale that it is cost-effective to provide this information and, then, the landlords' subsequent failure to provide reasons for a credit denial may appear to be evidence of pretextual discrimination.

160 See note 46 and accompanying text. 
owners of small businesses. ${ }^{161}$ We should not weigh the benefit of added tenant protections without considering the potential costs to landlords, involved in many repeat lease transactions over time, of having to keep a record of the reasons for every adverse action against every potential tenant and complying with the intricacies of the ECOA requirements. Even assuming this reporting burden is low, the added liability faced by landlords might be sufficient to drive some out of business, and cause others to raise rents. Both outcomes would be perverse if our goal is to provide optimal tenant protections because tenants would be left worse off, with a depleted housing stock and higher rents. ${ }^{162}$

On the other hand, the value of the improved FHA enforcement (through increased meritorious lawsuits) will likely overwhelm any rent increase or depletion in the housing stock caused by ECOA-mandated reporting. ${ }^{1.3}$ First, to the extent landlords keep some records and provide some notice in the status quo, the additional cost of record keeping and reporting imposed by the ECOA may be insignificant. ${ }^{164}$ Second, we can expect the non-trivial cost of liability for illegal discrimination to be distributed consistent with the antidiscriminatory aim of the FHA. Landlords using bad credit as a pretext for discrimination will suffer increased liability costs should they continue discriminating, thereby disadvantaging them as compared to competing nondiscriminatory landlords. Third, even the most disadvantaged tenants might find their options improved if landlords distribute any added costs across all tenants. ${ }^{165}$ Finally, more effective enforcement of the FHA could benefit all tenants by strengthening the societal norm against discrimination.

161 See 12 CFR $\$ 202$ Supplementary Information ("[C]ore provisions of Regulation B if applied to leasing transactions could impose significant burdens for certain segments of the industry."). The applicability of the ECOA to "creditors" receiving applications for credit, without exception, might also suggest Congress did not intend to even include landlords or leases. If Congress thought leases were covered, they would have made a small landlord exception like they do when landlords are covered everywhere else.

162 See Charles J. Meyers, The Covenant of Habitability and the American Law Institute, 27 Stan L Rev 879 (1975) (arguing that the cost of tenant protections and landlord burdens is ultimately passed on to consumers of rental housing). For a concise explanation of the argument that tenant protections hurt the people they are supposed to help, see Edward H. Rabin, The Revolution in Residential Landlord-Tenant Law: Causes and Consequences, 69 Cornell L Rev 517, 578 (1984) (concluding that " $[\mathrm{t}]$ he highly plausible theory that increased tenant protections ... would reduce the supply of rental housing has been neither proved nor disproved").

163 See Richard S. Markovits, The Distributive Impact, Allocative Efficiency, and Overall Desirability of Ideal Housing Codes: Some Theoretical Clarifications, 89 Harv L Rev 1815 (1976) (arguing that vigorous code enforcement will help tenants on balance).

164 For example, landlords legitimately denying leases based on poor credit already possess the specific reasons for denial; they need only put it on paper and mail it to the denied applicant.

165 Bruce Ackerman, Regulating Slum Markets on Behalf of the Poor: Of Housing Codes, Housing Subsidies and Income Redistribution Policy, 80 Yale L J 1093 (1971) (arguing, under specified conditions, enforcement of laws requiring improved housing conditions could benefit tenants without raising rents). 
One might argue the proposal advanced thus far resembles a "caseby-case" analysis in the sense that the Comment suggests that courts look at the text of each lease under review and then determine whether that particular lease meets the definition of credit. Such a case-by-case approach could be fraught with high decision costs for courts ${ }^{166}$ and inconsistent outcomes. This criticism is not particularly powerful for two reasons. First, most landlords use standard form leases ${ }^{167}$ and parties rarely demand alterations from the standard form. The prevalence of standard form leases means that the explicit text of most residential leases will vary little within an individual state. Given this uniformity, ${ }^{168}$ many courts

166 "Decision costs" refer to the resources expended to reach a consensual outcome, such as the cost of gathering information. See James M. Buchanan and Gordon Tullock, The Calculus of Consent: Logical Foundations of Constitutional Democracy vi-vii, 3 (Michigan 1965) (concluding that the best decision rule will minimize the sum of decision costs and error costs).

167 For an example of a standard form lease that (excluding mandatory state rules modifying it) appears to avoid deferred payment and, therefore, ECOA categorization as "credit," see Sanford Kahn, American Legal Forms No 104, Chicago Apartment Lease (unfurnished) 914 Forcible Detainer (1981, revised Jan 1995) ("If lessee defaults in the payment of rent ... Lessor may distrain for

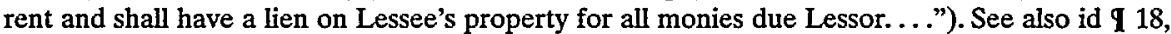
Surrender of Premises and Return of Possession ("At the termination of this Lease, by lapse of time or otherwise, Lessee shall yield up and surrender immediate possession to Lessor .... If Lessee fails to vacate... Lessee shall pay a sum equal to double the amount of rent ...").

168 Reliance on individual states' standard form leases may create a lack of uniformity. Similarly, the relevant background law may vary from state to state. However, the differing standard form leases and mandatory laws of the several states should not undermine the predictability of such a regime. While different state laws may result in the same lease agreement being categorized differently as governing law changes, both because certain explicit provisions honored in state $A$ will not be honored in state $B$ and because certain terms will be imported into the contract in state $A$ that will not be presumed in state $B$, the categorization rendered under the laws of a given state should remain consistent.

Because states control the content of their own standard lease forms, they may have an incentive to alter the content of such forms either to bring them under the protection of the ECOA, or, perhaps more disturbingly, to circumvent the protections of the ECOA. This criticism may be overstated for a few reasons. First, in order to have any bite it requires proof that states would "race to the bottom" in order to provide a climate more conducive to landlords. Absent proof that landlords have significant political strength unopposed by tenants or proof that states have an incentive to attract landlords (who do not benefit states through tax dollars in the same way and to the same extent as big business) we need not fear such a race to the bottom. Beyond these initial factors, it is unlikely that residential landlords would move from state to state based on the marginal cost of an additional reporting requirement especially when landlords, because they own property in a given state, cannot just pick up and move. In short, there is little evidence that states have an incentive to race to underprotect tenants in favor of landlords.

A related concern is that since the ECOA is a federal law granting a substantive right to be free from discrimination, we are faced with a perverse outcome in a world where the ECOA applies in some states and not in others. The concem is not a race to the bottom, but each state reacting in its own way to a de facto delegation to the states of the power to require ECOA disclosures by landlords. Even if not a single landlord moves, landlords may lobby for revision of the mandatory lease provisions. This criticism is similarly overstated. States that differ over whether the ECOA applies to residential leases will not differ over the level of permissible discrimination against tenants - this is established by the federal floors created in the FHA, for example. At most, we will have variation between states on a procedural issue, that is, whether disappointed would-be tenants have the fortune of being privy to the reasons landlords found their credit reports deficient. While such information helps undermine landlord circumvention of the FHA by exposing pretextual "bad credit" claims, see 
will incur minimal decision costs in determining whether a housing lease constitutes credit. A related point is that often the implicit terms of the lease, that is, the terms that are a function of the surrounding body of state law that is imported into the lease contract, are mandatory terms. ${ }^{169}$ In other words, requirements that leases permit the lessee to maintain possession for a fixed period even absent rent payment are often nonwaivable. This nonwaivability simplifies the analysis because it means that, within a particular state, the mandatory terms implicitly governing the lease will not change from case to case and, as a result, decision costs will turn out to be relatively low. This argument, of course, does not apply to terms that vary from lease to lease-where there is no mandatory term-and that affect whether a particular lease constitutes "credit."

\section{CONCLUSION}

The ECOA is the only federal law that requires creditors to disclose to disappointed applicants the specific reason their credit is deficient should applicants be denied based on their credit reports. Such disclosure could be extremely useful to would-be tenants who are suing under housing discrimination laws such as the FHA and CRA.

This Comment suggests that whether leases are governed by the ECOA, and thus subject to its reporting requirement, turns on whether leases constitute credit. This question, to date, has been answered by making determinations about the general characteristics of leases and then comparing these qualities with the characteristics of credit transactions. This Comment argues that it is better to adopt an approach that focuses on the specific terms of the lease agreement at issue and on the content of applicable state law governing the specific lease in order to determine whether the given lease resembles a credit transaction.

Part I.C, its availability does not affect the existence of the substantive protections enjoyed by each tenant.

169 See notes 146, 149, 150 and accompanying text (discussing mandatory rules governing possession of leased property). 